\title{
BATALLAS FÍLMICAS POR LOS DERECHOS DE LA MUJER
}

\author{
Film Battles for Women's Right
}

Eddy Chávez Huanca ${ }^{1}$

La vigencia de nuestros derechos relata la presencia de los principios universales de la humanidad, aquellos proclamados en revoluciones y sendas reformas que buscaban decir basta al status quo donde el derecho solo reflejaba un sostén perverso para apuntalar a los grupos de poder. Construir la democracia moderna dándole vitalidad a las proclamas y contenidos de la democracia ha sido tarea de varias generaciones. Libertad, igualdad, fraternidad, resistencia a la opresión, hoy en día ya son proclamas de la edad moderna de la civilización.

Si dichas proclamas han logrado materializarse dentro de un sistema jurídico, la civilización ha avanzado $\mathrm{y}$, si dichas proclamas tienen vigencia con un alcance universal, los derechos son más que mera ideología o prosa literaria, los derechos terminan teniendo vigencia. Y, una etapa de esa presencia es la lucha por lograrlo, la discusión por ampliar dicha vigencia a todos los escenarios, no solo a los occidentales europeos.

A la presente fecha, cabe preguntarnos ¿qué tanto hemos hecho los abogados desde nuestras diversas actividades para que dichas proclamas tengan vigencia? Dichas reivindicaciones han costado muchas vidas de gente buena, dicho sacrificio ha dado como fruto un mundo que busca permanentemente la paz social construida a través de un sistema jurídico del que todos debemos formar parte.

Paulatinamente vamos ingresando al siglo veintiuno en una velocidad que la postmodernidad hace erosionar las reglas de juego convencionales, las luchas sociales ya no son más focos locales o regionales, son ahora globales. Ante ello, el derecho pierde eficacia sino asimila creativamente un derecho unificador fruto de la globalización y demás ecos postmodernos que hacen del mundo un camino sin fin y con múltiples cercanías, donde conocemos culturas que antes de la era digital habrían estado envueltas en enigmas y creencias sujetas a la ajenidad.

Gracias al mundo red, hoy es posible conocer las luchas de reivindicación social que están librando las mujeres en África, Medio Oriente, Centroamérica, Brasil, por mencionar escenarios que hoy se nos aproximan gracias a la internet y la comunicación en tiempo real, la lucha por la vigencia de los derechos de la mujer en igualdad

\footnotetext{
${ }^{1}$ Abogado, miembro colaborador del Instituto Riva-Agüero de la PUCP, miembro del Instituto Latinoamericano de Historia y Derecho, miembro del Consejo Consultivo de la Revista Transversos de la Universidad del Estado de Río de Janeiro - Brasil (UERJ). Director de la Red Iberoamericana de Cine y Derecho, profesor de Filosofía del Derecho e Historia del Derecho en la Universidad Continental. Huancayo, Perú. Director de la serie Cine y Derecho y de la Colección Pensamiento Iberoamericano que se publica en editorial Grijley de Lima - Perú. Correo electrónico: echavez_77@hotmail.com
} 
de condiciones es una lucha global. Los movimientos sociales, movimientos feministas, de reivindicación, de protesta y toda aquella que busca exigir para la mujer la vigencia de su dignidad y acabar con esa postergación histórica de la cual han sido afectadas números mayoritarios de las mismas, busca que en los inicios del siglo veintiuno llegué a su fin dicha desigualdad.

Es un hecho que la historia ha tenido como eje central un relato mayoritariamente construido por varones, quienes han dirigido la más de las veces a considerar con mayor voluntad el papel de los varones en el trazo histórico de la humanidad y, la atención sobre el rol de la mujer en la historia ha sido invisibilizada si es que no olvidada. Cuantas historias de mujeres revolucionarias, patriotas, abogadas, que han luchado por los derechos de la mujer no llegaremos a conocer, el relato histórico no se ha ocupado de ellas con el mismo énfasis, o han sido minimizadas.

La memoria de los pueblos y el relato de ficción han sido de mucha ayuda para dar a conocer los males del machismo y combatirlo si fuere posible. Han servido de insumo para aparejar la postergación y el desbalance histórico con las que se ha acometido el rol de la mujer en la historia. Ha sido y es de gran ayuda el cine para recrear, recordar, imaginar, especular e ir por más para reivindicar el papel de la mujer en los grandes cambios sociales que no solo han afectado a su género sino a todos.

Michael Moore, documentalista norteamericano -antisistema además- tiene un discurso de denuncia respecto del actual momento que vive su país (inicios del siglo XXI), ante ello en sus trabajos -no ajenos a la provocación- exhibe situaciones complejas, como la tenencia libre de armas, el sistema económico monetarista, los ecos perjudiciales para los derechos del trabajador que ocasiona la globalización y así, llega a proponer en uno de sus últimos trabajos titulado Trumphland (USA, 2016)- título en alusión al en ese entonces candidato a la presidencia de USA Donald Trumpel rol histórico de la mujer en el siglo veintiuno, donde se institucionaliza su acceso a la dirección y organización de la sociedad, incluso con mayor presencia que los varones.

Una de sus reflexiones es señalar que la hora de las mujeres ha llegado, que, la férrea resistencia del machismo a esos cambios se manifiesta en intolerancia contra las minorías, contra el "extranjero" -cosa cada vez extraña hablar de extranjeros, frente al presente de la humanidad que la actual situación fomenta una ciudadanía mundial donde el pasaporte y la visa deben ser cosa del pasado. Por más utópico que suene, debemos destruir esas certificaciones para que los seres humanos podamos trasladarnos libremente de un lugar a otro-.

Ser mujer fuera del hogar ha resultado una afrenta a los convencionalismos implantados en la sociedad por el machismo. Históricamente, lo meritorio y su reconocimiento social han estado reflejados en el trabajo fuera del hogar -como si criar y educar a los hombres fuera cosa menor-, logros científicos y profesiones donde las decisiones políticas y acceso al poder casi en su totalidad han sido construidos y desarrollados solo para varones. Aun vivimos tiempos donde oímos "la primera mujer en graduarse" "la primera mujer en ser recibida en tal institución" y así..., construir un escenario donde sea cotidiano el debate sobre la vigencia de los derechos de la mujer es algo que debemos conseguir.

El director de cine Martin Ritt construye un relato fílmico biográfico titulado Norma Rae (USA, 1979), un drama basado en hechos reales donde una mujer, madre soltera, obrera, divorciada, en un escenario donde los trabajadores son de condición humilde y viven sometidos por la necesidad de tener un trabajo y aceptar las condiciones laborales que abusan de la necesidad y lindan con la humillación de los trabajadores. Ella se propone organizar un sindicato, primero deberá convencer a sus compañeros, luego enfrentarse a los propietarios a costa de perder su trabajo y por ello, dejar en la intemperie a su familia, logra su cometido y el cine nos hereda una de las imágenes más representativas de la lucha de la mujer por los derechos laborales. 
El siglo veintiuno es el siglo de las imágenes en movimiento, donde el protagonismo de las pantallas performan nuestra forma de vivir, pantallas para todos y por todos lados, que vigilan, que relatan historias, la vida se ha convertido en una vida de cine, hoy más que nunca el alcance de la información audiovisual está acercando culturas y exhibiendo los dilemas de nuestras vidas. No podemos ser ajenos a esos cambios y debe servirnos para debatir la vigencia de los derechos de la mujer, en este caso a través del cine.

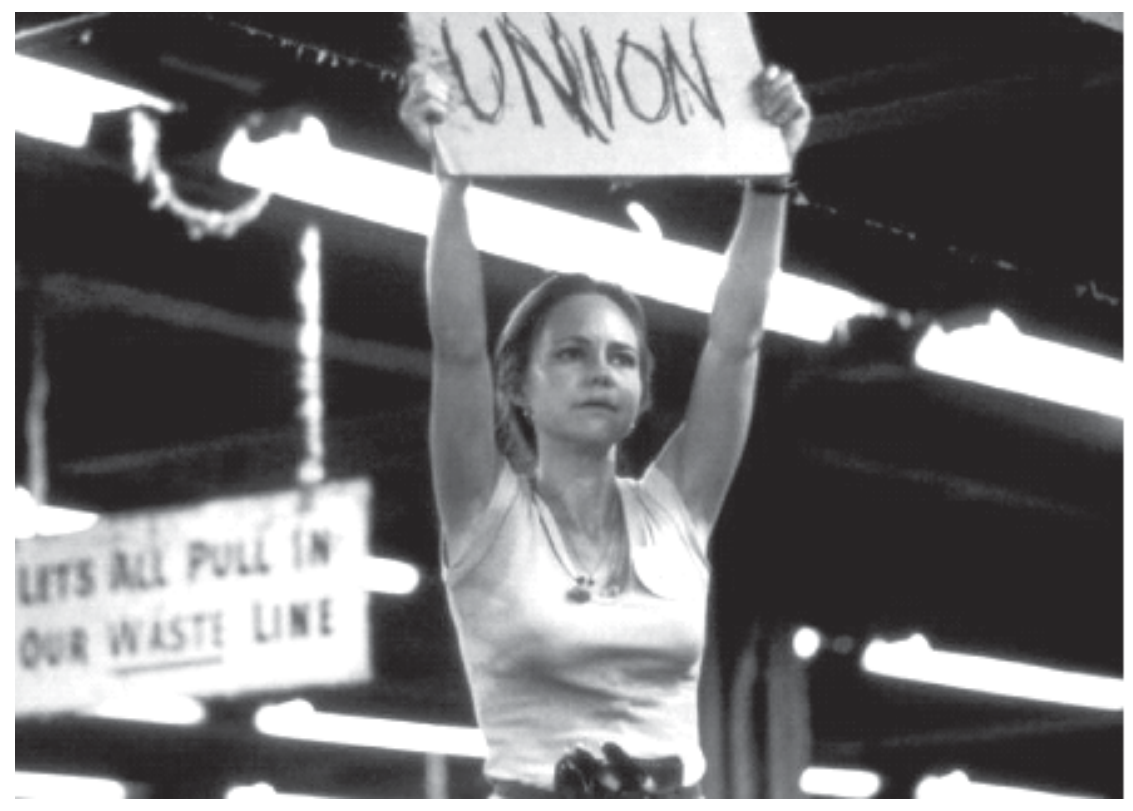

Sally Field interpretando a Norma Rae, líder sindical en una de las imágenes icónicas del cine y la lucha por los derechos de la mujer (USA, 1979) 